\title{
EFFECT OF MUNICIPAL SOLID WASTE INCINERATION FLY ASH ON THE PROPERTIES, MICROSTRUCTURE AND DURABILITY OF CLAY BRICKS
}

\author{
VIOLETA VOIŠNIENE**, "OLGA KIZINIEVIČ**, VIKTOR KIZINIEVIČ** \\ *Department of Chemistry and Bioengineering, Vilnius Gediminas Technical University, \\ Sauletekio aw. 11, LT 10223 Vilnius, Lithuania \\ **Laboratory of Composite Materials, Institute of Building Materials, Vilnius Gediminas Technical University, \\ Linkmenu g. 28, LT 08217 Vilnius, Lithuania \\ \#E-mail: olga.kizinievic@vgtu.lt
}

Submitted April 22, 2020; accepted June 8, 2020

\begin{abstract}
Keywords: Municipal solid waste incineration, Fly ash, Waste recycling, Clay brick, Leaching, Durability, Freeze - thaw resistance

The paper analyses the effect of municipal solid waste incineration fly ash (MWSI FA) on the physical-mechanical characteristics, environmental toxicity, microstructure and durability (freeze - thaw resistance) of clay bricks. The clay bricks were prepared by adding $2.5-7.5 \% \mathrm{FA}$ and firing them at a temperature of $1000{ }^{\circ} \mathrm{C}$. The physical and mechanical characteristics of the clay brick change depending on the content of the FA added: the shrinkage, density and compressive strength decreases, while the water absorption and total porosity increases. Also, the mineral composition of the ceramic bodies changed with the FA additions. Clay bricks containing $2.5 \%$ FA do not exceed the limit values of non-hazardous substances according to the Waste Directive 2003/33/EC. The recommended limits of the fly ash addition to the clay brick moulding are $2.5 \mathrm{wt} . \%$. In terms of resistance to freezing and thawing cycles, such products are regarded as freeze-thaw resistant in middle aggressive environments, i.e., in structures protected from direct environmental effects (Class F1 according to the EN 771-1:2011+A1:2015 standard).
\end{abstract}

\section{INTRODUCTION}

Municipal waste is used for energy production through incineration at a temperature of $1000{ }^{\circ} \mathrm{C}$. The thermal treatment results in the reduction of the municipal waste mass by $65-80 \%$ and the volume by $85-90 \%$ [1].

Incineration of municipal waste mainly produces slag (bottom ash) of about $95-97 \%$ and the remaining part (from $3 \%$ to $5 \%$ ) is fly ash $[2,3]$. According to the European Waste Catalogue (EWC) edited in 2015, fly ash, a by-product of municipal solid waste incineration (MSWI), is classified as hazardous waste (code 1901 13) because it contains large amounts of heavy metals, chlorides, sulfates. The chemical composition and amount of fly ash generated by the incineration of municipal waste depend on the original composition of the initial raw material, the used incineration technology and the design of air pollution control system.

A literature analysis revealed that the main components of fly ash are $\mathrm{CaO}, \mathrm{SiO}_{2}$ and $\mathrm{Al}_{2} \mathrm{O}_{3}$ [4-6]. There is also a significant chloride content. Some authors find a rather high loss on ignition (usually measured at a temperature of $1000-1200^{\circ} \mathrm{C}$ ). A high loss on ignition indicates that the fly ash contains high levels of inorganic salts, such as calcite, chlorides and sulfates [6].
Fly ash also contains high levels of heavy metals, such as $\mathrm{Zn}, \mathrm{Pb}, \mathrm{Cu}, \mathrm{Cd}, \mathrm{Cr}$ and other ones [7-9]. A mineral composition analysis of fly ash mainly reveals the presence of the following minerals $\mathrm{SiO}_{2}, \mathrm{NaCl}, \mathrm{KCl}$, $\mathrm{CaSO}_{4}, \mathrm{CaCO}_{3}[10,11,7]$.

The relevance of the disposal of MSWI fly ash in clay brick manufacturing lies in the need to bind or immobilise heavy metals at a high temperature by turning them into insoluble compounds. At high temperatures, $\mathrm{Pb}$ and $\mathrm{Zn}$ are encapsulated inside the clay brick and their leaching values are significantly reduced [12, 13].

The chemical composition of MSWI fly ash covers a wide range [14-16]. Therefore, the fly ash content in clay bricks recommended by the authors is also different [17-20]. The authors [17] propose to add $1-10 \%$ of fly ash and $15-35 \%$ of marble waste to a ceramic brick moulding compound and fire the bricks at a temperature of $975-1050{ }^{\circ} \mathrm{C}$. It was found that with a higher fly ash content, the flexural strength decreases and the water absorption increases

It was proven/demonstrated that clay bricks containing water treated fly ash have better physical and me-chanical characteristics compared to unmodified clay bricks. The proposed FAW (washed MSWI fly ash) content is $5 \mathrm{wt}$ \%. Such products have a density

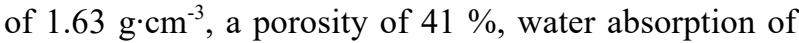
$25.5 \%$, and a compressive strength of $8 \mathrm{MPa}$ [18]. 
Clay products containing $20-40 \%$ of fly ash have a density of $1313-1578 \mathrm{~kg} \cdot \mathrm{m}^{-3}\left(1.313-1.578 \mathrm{~g} \cdot \mathrm{cm}^{-3}\right)$ and a total open porosity of $42.1-51.01 \%$. Tests of heavy metals leaching from ceramic products containing fly ash revealed high leachate values, which exceed the limits set forth in normative documents [19]. The authors [20] propose to manufacture bricks using $20 \%$ of MSWI fly ash, $60 \%$ of clay, $10 \%$ of feldspars and $10 \%$ of sand. Ceramic bodies fired at a temperature of $950{ }^{\circ} \mathrm{C}$ have water absorption below $11 \%$, a compressive strength of $16 \mathrm{MPa}$, and shrinkage of $0.19 \%$.

It should be also noted that scientists [18-20] in different countries most often analyse the effect of the MSWI fly ash on the physical and mechanical characteristics and environmental toxicity of fired clay bricks. The present paper suggests that the microstructure and durability (resistance to freezing and thawing cycles) are important characteristics to be analysed as well.

\section{EXPERIMENTAL}

Clay, sand and fly ash are used in this experimental research. The clay and sand were dried at a temperature of $100 \pm 5{ }^{\circ} \mathrm{C}$, crushed and sieved through a $1.25 \mathrm{~mm}$ sieve. The FA was collected from a municipal waste cogeneration power plant. The FA eluate was produced in accordance with standard EN 13657. The paper analyses the FA eluate values obtained in the tests performed in the period from 09-01-2017 till 05-07-2017. All the analysed moulding compounds were prepared in the same manner by changing the content of the fly ash (FA) in the moulding composition (Table 1). $70 \times 70 \times 70 \mathrm{~mm}$ and $50 \times 50 \times 50 \mathrm{~mm}$ size specimens were formed from the moulding compounds, the composition of which is presented in Table 1.

Table 1. Composition of moulding compounds.

\begin{tabular}{llcc}
\hline $\begin{array}{l}\text { Moulding } \\
\text { compounds }\end{array}$ & \multicolumn{3}{c}{ Raw materials } \\
\cline { 2 - 4 } & Clay & Sand & FA and FAW* \\
\hline CS & 90 & 10 & 0 \\
FA2.5 & 87.5 & 10 & 2.5 \\
FA5.0 & 85.0 & 10 & 5.0 \\
FA7.5 & 82.5 & 10 & 7.5 \\
\hline
\end{tabular}

Note: $\mathrm{CS}$ is the reference sample

The technological parameters (Atterberg limits) of the moulding compounds are presented in Table 2. It was found that higher amounts of FA added to the moulding mixtures demand more water to obtain the required consistency of the reference one. Subsequently, the liquid limit and plastic limit of the moulding increase and the plasticity index decreases. Fly ash from municipal waste is considered to be a non-plastic material and the same is evidenced by the reduced plasticity index at the higher waste content in the moulding. The drop in the plasticity index with the higher content of the thinning non-plastic additions was also proven by other authors [21-23]. According to the authors $[24,25]$ and the ASTM D4318 standard, moulding compounds with a plasticity index ranging from 7 to 17 are graded as moulding compounds of average plasticity.

Table 2. The technological parameters (Atterberg limits) of the moulding compounds.

\begin{tabular}{lccc}
\hline $\begin{array}{l}\text { Moulding } \\
\text { compounds }\end{array}$ & \multicolumn{3}{c}{ Technological parameters } \\
\cline { 2 - 4 } & $\begin{array}{c}\text { Liquid limit } \\
(\%)\end{array}$ & $\begin{array}{c}\text { Plastic limit } \\
(\%)\end{array}$ & $\begin{array}{c}\text { Plasticity } \\
\text { index }\end{array}$ \\
\hline C & $35 \pm 0.3$ & $16.5 \pm 0.1$ & $18.5 \pm 0.2$ \\
CS & $36.2 \pm 0.1$ & $18.2 \pm 0.2$ & $18.0 \pm 0.3$ \\
FA2.5 & $37.6 \pm 0.2$ & $20.5 \pm 0.2$ & $17.1 \pm 0.2$ \\
FA5 & $38.6 \pm 0.3$ & $22.6 \pm 0.3$ & $16.0 \pm 0.2$ \\
FA7.5 & $39.4 \pm 0.2$ & $23.9 \pm 0.2$ & $15.5 \pm 0.3$ \\
\hline
\end{tabular}

Note: $C S$ is the reference sample, $C$ is the clay sample

The specimens were initially dried for 72 hours in a natural laboratory environment $\left(18 \pm 5^{\circ} \mathrm{C}\right)$. Later, the specimens were dried according to the selected regime: at $60 \pm 5{ }^{\circ} \mathrm{C}$ on the first day and at $105 \pm 5{ }^{\circ} \mathrm{C}$ on the second day. The specimens were fired at $1000{ }^{\circ} \mathrm{C}$; the firing time was one hour.

A classical chemical analysis was used to determine the chemical composition of the primary silicate raw materials used for the tests by means of an INCA PentaFET $\times 3 \mathrm{Si}(\mathrm{Li})$ detector from Oxford Instruments.

The concentration of heavy metals in the eluate from the clay bricks was determined by the atomic absorption spectral analysis method using a Buck Scientific 2010 VGP spectrometer with an air-acetylene flame. The eluate was prepared according to the LST EN 12457-2:2003 standard. The solution for the $\mathrm{pH}$ and specific conductivity tests was prepared from $2 \mathrm{~g}$ of the test material and $100 \mathrm{~g}$ of distilled water. The prepared solution was agitated for 45 minutes in a magnetic stirrer, filtered afterwards and tested. The specific conductivity was measured by a Cond $315 \mathrm{i}$ electric conductivity meter equipped with a Tetra Con 325 electrode. The alkalinity of the solution was measured by a HANA HI $9321 \mathrm{pH}$ meter.

The particle size distribution was identified by means of a Cilas 1090 liquid analyser. The X-ray diffraction analysis was conducted using a DRON-7 X-ray diffractometer (a Co anode and an Fe filter) and a SmatLab X-ray diffraction meter equipped with a rotating $\mathrm{Cu}$ anode of $9 \mathrm{~kW}$ capacity. The microstructure was analysed by means of a SEM Quanta 250 with an SE detector.

The physical and mechanical characteristics of the fired specimens were determined in accordance with standard testing methodologies: the density was determined in accordance with the LST EN 772-13:2003 standard; the water absorption was determined in accordance with the LST EN 772-21:2011 standard; the 
compressive strength was determined in accordance with the LST EN 772-1:2011 standard. The effective porosity, total open porosity, relative thickness of the pore and capillary walls were determined in accordance with the methodology described in the literature [26]. The microstructure was analysed by means of a SEM Quanta 250 with an SE detector.

The durability of the fired specimens was evaluated by their resistance to the all-side and one-side freezing and thawing cycles:

- one-side freeze - the thaw method in accordance with the CEN/TS 772-22:2006 standard "Methods of test for masonry units - Part 22: Determination of the freeze/thaw resistance of clay masonry units" and the LST 1985:2006 standard "Determination of freeze and thaw resistance of clay masonry units";

- all-side freeze - the thaw method in accordance with the CEN/TS 1985-22:2006 standard "Methods of test for masonry units - Part 22.

The drying shrinkage and firing shrinkage were calculated from Equations 1 and 2 below.

$$
\begin{gathered}
L=\frac{L_{0}-L_{1}}{L_{0}} * 100 \% \\
L_{B}=\frac{L_{0}-L_{2}}{L_{0}} * 100 \%
\end{gathered}
$$

where $L_{0}$ is the distance between the markings in the wet specimen $(\mathrm{mm}) ; L_{1}$ is the distance between the markings in the dried specimen, $\mathrm{mm} ; L_{2}$ is the distance between the markings in the fired specimen, in $\mathrm{mm}$.

The two sided confidence intervals with a confidence level of 0.95 of the measured quantities (porosities, shrinkage, density, water absorption, strength) of the sample means were calculated by assuming that the samples are distributed according to the Normal law and Student's $t$-test distribution was applied for the cal- culation of the confidence intervals: $\left(m-t_{d,(1 \alpha / 2)} \cdot s / \sqrt{ } n\right) \leq$ $\leq \mu \leq\left(m+t_{d,(1 \alpha / 2)} \cdot s / \sqrt{ } n\right)$, where $m, s$ and $n=6$ are the estimations of the mean, standard deviation and sample size, respectively, $t_{d,(1 \alpha / 2)} \approx 2.57$ is the $(1-\alpha / 2)=0.975$ quantile of the Student's t-test distribution, where $\alpha=0.05$ is the level of significance and $d=n-1=5$ is the degree of freedom. The numbers written in the $m \pm \Delta$ format in the figures and tables of this paper represent the values of the corresponding sample means, the letter $m$, and the deviations of the limits of confidence intervals of the porosities $\Delta=t_{d,(1 \alpha / 2)} \cdot s / \sqrt{ } n$.

\section{RESULTS AND DISCUSSION}

The chemical composition and particle size distribution of the clay are presented in Tables 3 and 4 . The clay contained sufficient amounts of $\mathrm{Al}_{2} \mathrm{O}_{3}+\mathrm{TiO}_{2}$ and $\mathrm{Fe}_{2} \mathrm{O}_{3}$, and rather small amounts of $\mathrm{CaO}+\mathrm{MgO}$. The high level of $\mathrm{Fe}_{2} \mathrm{O}_{3}$ and low level of $\mathrm{CaO}+\mathrm{MgO}$ may influence the colour of the final product and the high content of organic impurities may cause the swelling of the clay brick. The clay contains $84.5 \%$ clay fraction. It has the plasticity index of 18.5 and, thus, can be graded as clay of average plasticity. The chemical composition and particle size distribution in the sand are presented in Table 3 and Table 5.

The analysis of clay microstructure is presented in Figure 1a. The clay particles are plate shaped and distributed evenly. The clay particles are in contact with particles of other substances via thin clay particle bridges; particulate debris is present among the clay plates, the size of plates ranges from $0.5 \mu \mathrm{m}$ to $9.0 \mu \mathrm{m}$. The X-ray tests of the clay showed that the following minerals prevail: mica (muscovite) $(\mathrm{K}-\mathrm{Mg}-\mathrm{Fe}-\mathrm{Al}-\mathrm{Si}-$ $\left.-\mathrm{O}-\mathrm{H}_{2} \mathrm{O}\right)$, quartz, $\left(\mathrm{SiO}_{2}\right)$, feldspars $\left(\mathrm{CaAlSi}_{3} \mathrm{O}_{8}\right)$, kaolinite $\left(\mathrm{Al}_{2 \mathrm{Si2O}}(\mathrm{OH})_{4}\right)$ (Figure $1 \mathrm{~b}$ ).

Table 3. The chemical composition of the clay.

\begin{tabular}{lcccccccc}
\hline \multirow{2}{*}{ Raw } & \multicolumn{7}{c}{ Chemical composition (\%) } \\
\cline { 2 - 9 } & $\mathrm{SiO}_{2}$ & $\mathrm{Al}_{2} \mathrm{O}_{3}+\mathrm{TiO}_{2}$ & $\mathrm{Fe}_{2} \mathrm{O}_{3}$ & $\mathrm{CaO}$ & $\mathrm{MgO}$ & $\mathrm{Na}_{2} \mathrm{O}$ & $\mathrm{K}_{2} \mathrm{O}$ & L.o.i \\
\hline Clay & 51.43 & 20.54 & 7.44 & 4.26 & 3.07 & 0.42 & 3.3 & 9.54 \\
Sand & 98.5 & $<0.60 \%$ & $<0.05$ & - & - & - & - & - \\
\hline
\end{tabular}

Table 4. The particle size distribution in the clay.

\begin{tabular}{lccccc}
\hline \multirow{2}{*}{ Raw } & \multicolumn{5}{c}{ Amount (\%) } \\
\cline { 2 - 6 } & $>0.25 \mathrm{~mm}$ & $0.25-0.05 \mathrm{~mm}$ & $0.05-0.005 \mathrm{~mm}$ & $0.05-0.001 \mathrm{~mm}$ & $<0.001 \mathrm{~mm}$ \\
\hline Clay & 0.10. & 0.52 & 14.85 & 25.67 & 58.86 \\
\hline
\end{tabular}

Table 5. The particle size distribution in the sand.

\begin{tabular}{ccccccccccccc}
\hline Raw & $2500 \mu \mathrm{m}$ & $1250 \mu \mathrm{m}$ & $1000 \mu \mathrm{m}$ & $800 \mu \mathrm{m}$ & $630 \mu \mathrm{m}$ & $400 \mu \mathrm{m}$ & $315 \mu \mathrm{m}$ & $200 \mu \mathrm{m}$ & $160 \mu \mathrm{m}$ & $100 \mu \mathrm{m}$ & $63 \mu \mathrm{m}$ & $50 \mu \mathrm{m}$ \\
\hline Sand & 0.10 & 0.20 & 0.30 & 1.50 & 2.70 & 7.50 & 9.40 & 34.40 & 17.20 & 17.80 & 8.30 & 0.65 \\
\hline
\end{tabular}




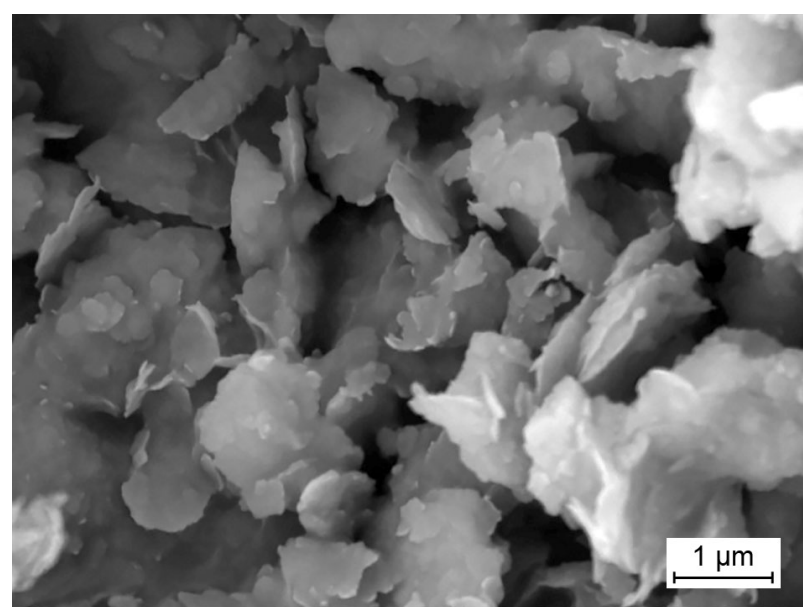

a)

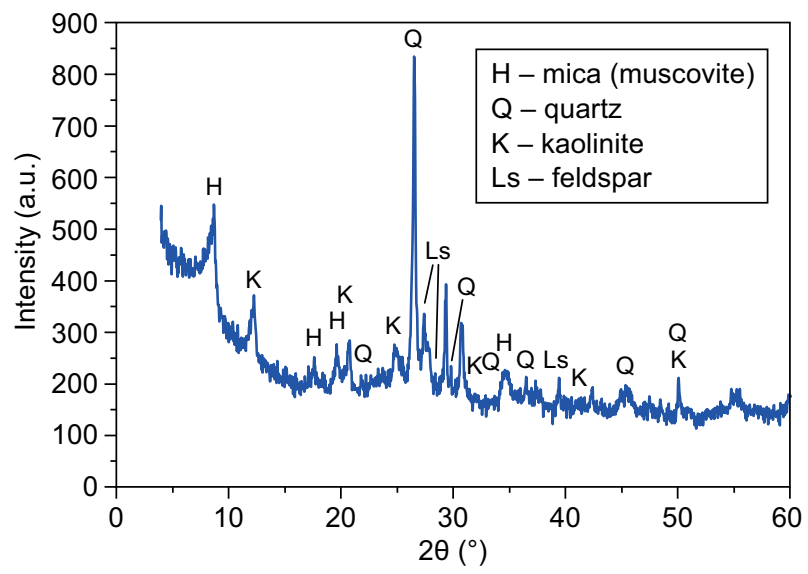

b)

Figure 1. The microstructure (a) and the X-ray diffraction pattern (b) of the clay (nm).

Table 6. The FA eluate test results.

\begin{tabular}{|c|c|c|}
\hline Title & $\begin{array}{c}\text { Range of the composition } \\
\text { [References] }\end{array}$ & $\begin{array}{l}\text { Test results of } \\
\text { the present work }\end{array}$ \\
\hline $\mathrm{P}_{2} \mathrm{O}_{5}$ & $0.30-0.55 \%$ & $0.55 \%$ \\
\hline $\mathrm{Na}_{2} \mathrm{O}$ & $2.65-3.68 \%$ & $2.65 \%$ \\
\hline $\mathrm{K}_{2} \mathrm{O}$ & $3.52-4.69 \%$ & $3.52 \%$ \\
\hline $\mathrm{MgO}$ & $1.15-1.39 \%$ & $1.15 \%$ \\
\hline $\mathrm{Mg}$ & $0.693-0.84 \%$ & $0.693 \%$ \\
\hline $\mathrm{CaO}$ & $40.6-45.17 \%$ & $45.17 \%$ \\
\hline $\mathrm{SiO}_{2}$ & $0.081-0.23 \%$ & $0.23 \%$ \\
\hline $\mathrm{Al}_{2} \mathrm{O}_{3}$ & $1.08-2.56 \%$ & $1.08 \%$ \\
\hline $\mathrm{Al}$ & $0.573-1.35 \%$ & $0.573 \%$ \\
\hline $\mathrm{TiO}_{2}$ & $1543-3245 \mathrm{mg} \cdot \mathrm{kg}^{-1}$ & $1543 \mathrm{mg} \cdot \mathrm{kg}^{-1}$ \\
\hline Titanium & $925-1945 \mathrm{mg} \cdot \mathrm{kg}^{-1}$ & $925 \mathrm{mg} \cdot \mathrm{kg}^{-1}$ \\
\hline $\mathrm{Fe}_{2} \mathrm{O}_{3}$ & $6938-9883 \mathrm{mg} \cdot \mathrm{kg}^{-1}$ & $6938 \mathrm{mg} \cdot \mathrm{kg}^{-1}$ \\
\hline Iron & $4853-6913 \mathrm{mg} \cdot \mathrm{kg}^{-1}$ & $4853 \mathrm{mg} \cdot \mathrm{kg}^{-1}$ \\
\hline$\overline{\mathrm{MnO}_{2}}$ & $334-755 \mathrm{mg} \cdot \mathrm{kg}^{-1}$ & $334 \mathrm{mg} \cdot \mathrm{kg}^{-1}$ \\
\hline Manganese & $259-477 \mathrm{mg} \cdot \mathrm{kg}^{-1}$ & $259 \mathrm{mg} \cdot \mathrm{kg}^{-1}$ \\
\hline Arsenic & $13.8-23.0 \mathrm{mg} \cdot \mathrm{kg}^{-1}$ & $\overline{13.8 \mathrm{mg} \cdot \mathrm{kg}^{-1}}$ \\
\hline$\overline{\text { Lead }}$ & $1987-3611 \mathrm{mg} \cdot \mathrm{kg}^{-1}$ & $1987 \mathrm{mg} \cdot \mathrm{kg}^{-1}$ \\
\hline Cadmium & $83.4-143.0 \mathrm{mg} \cdot \mathrm{kg}^{-1}$ & $83.4 \mathrm{mg} \cdot \mathrm{kg}^{-1}$ \\
\hline Chromium & $50.5-82.8 \mathrm{mg} \cdot \mathrm{kg}^{-1}$ & $50.5 \mathrm{mg} \cdot \mathrm{kg}^{-1}$ \\
\hline Copper & $625-1491 \mathrm{mg} \cdot \mathrm{kg}^{-1}$ & $625 \mathrm{mg} \cdot \mathrm{kg}^{-1}$ \\
\hline Nickel & $12.2-23.7 \mathrm{mg} \cdot \mathrm{kg}^{-1}$ & $12.2 \mathrm{mg} \cdot \mathrm{kg}^{-1}$ \\
\hline Mercury & $8.2-15.6 \mathrm{mg} \cdot \mathrm{kg}^{-1}$ & $10.4 \mathrm{mg} \cdot \mathrm{kg}^{-1}$ \\
\hline$\overline{\text { Zinc }}$ & $8827-14540 \mathrm{mg} \cdot \mathrm{kg}^{-1}$ & $10209 \mathrm{mg} \cdot \mathrm{kg}^{-1}$ \\
\hline Barium & $154-448 \mathrm{mg} \cdot \mathrm{kg}^{-1}$ & $237 \mathrm{mg} \cdot \mathrm{kg}^{-1}$ \\
\hline Molybdenum & $<1.0-1.90 \mathrm{mg} \cdot \mathrm{kg}^{-1}$ & $<1 \mathrm{mg} \cdot \mathrm{kg}^{-1}$ \\
\hline Tin & $301-412 \mathrm{mg} \cdot \mathrm{kg}^{-1}$ & $367 \mathrm{mg} \cdot \mathrm{kg}^{-1}$ \\
\hline Beryllium & $<1-1.17 \mathrm{mg} \cdot \mathrm{kg}^{-1}$ & $<1 \mathrm{mg} \cdot \mathrm{kg}^{-1}$ \\
\hline$\overline{\text { Cobalt }}$ & $5.99-14.4 \mathrm{mg} \cdot \mathrm{kg}^{-1}$ & $5.99 \mathrm{mg} \cdot \mathrm{kg}^{-1}$ \\
\hline$\overline{\mathrm{V}_{2} \mathrm{O}_{5}}$ & $9.55-28.6 \mathrm{mg} \cdot \mathrm{kg}^{-1}$ & $9.55 \mathrm{mg} \cdot \mathrm{kg}^{-1}$ \\
\hline Vanadium & $5.35-16.0 \mathrm{mg} \cdot \mathrm{kg}^{-1}$ & $5.35 \mathrm{mg} \cdot \mathrm{kg}^{-1}$ \\
\hline Tungsten & $<1-33.5 \mathrm{mg} \cdot \mathrm{kg}^{-1}$ & $<1 \mathrm{mg} \cdot \mathrm{kg}^{-1}$ \\
\hline Strontium & $239-296 \mathrm{mg} \cdot \mathrm{kg}^{-1}$ & $239 \mathrm{mg} \cdot \mathrm{kg}^{-1}$ \\
\hline
\end{tabular}


The FA eluate characteristics presented in Table 6 are taken from the tests performed in the period from 09-01-2017 till 05-07-2017. The range of the determined value is rather narrow. The data in Table 5 show that the FA contains a high amount $(45.17 \%)$ of $\mathrm{CaO}, 19.01 \%$ of chlorides (mainly $\mathrm{KCl}, \mathrm{NaCl}, \mathrm{MgCl}_{2}$ ), also traces of $\mathrm{Na}_{2} \mathrm{O}, \mathrm{K}_{2} \mathrm{O}, \mathrm{MgO}, \mathrm{Al}_{2} \mathrm{O}_{3}, \mathrm{Fe}_{2} \mathrm{O}_{3}$, and $\mathrm{TiO}_{2}$. It also contains the heavy metals: lead, cadmium, chromium, copper, mercury, molybdenum, tin, tungsten, strontium, etc.

The dry residue of the FA is $100 \%$, the humidity is $2-3 \%$, the total organic carbon is $1.48 \%$, and the sulfur content is $0.82 \%$. The FA has a specific electric conductivity of $15.26 \mu \mathrm{S} \cdot \mathrm{cm}^{-1}, \mathrm{pH}=11.93$.

The FA microstructure analysis revealed that the fly ash is amorphous and contains particles of different shapes. These particles have a round form, porous struc-ture and even surface. The smaller particles stick to coarser particles, thus, forming a heterogeneous structure (separate grains are clearly seen), the particle size is above $10 \mu \mathrm{m}$ (Figures $2 \mathrm{a}$ and $2 \mathrm{~b}$ ). The particles have a high closed porosity; the same is confirmed by the literature source [27]. Some authors argue [28] that the high closed porosity of fly ash is closely related to the leaching of heavy metals.

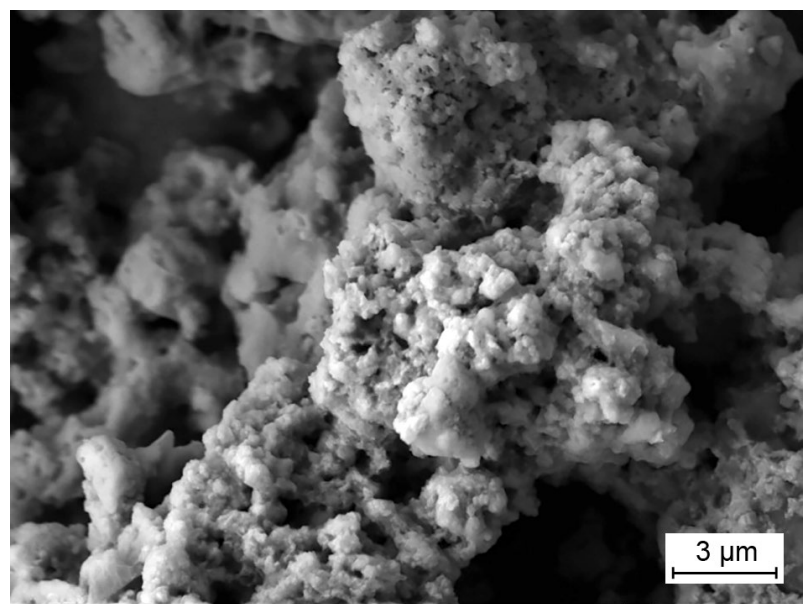

a)

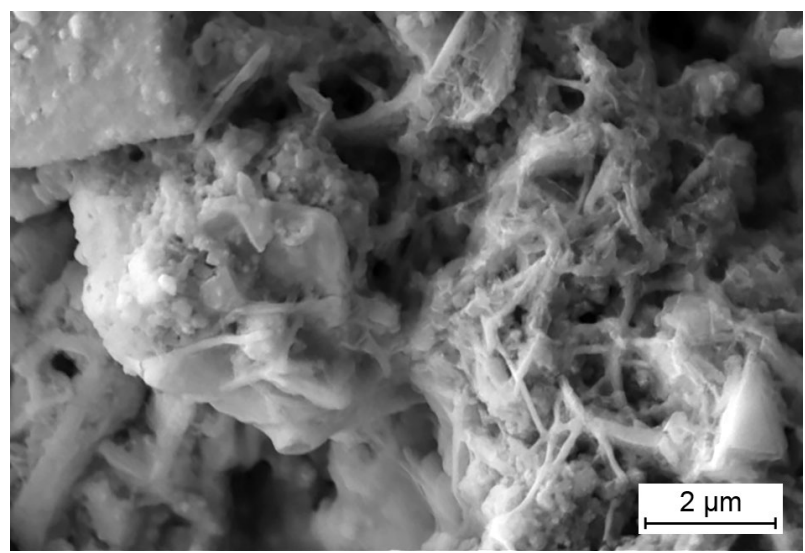

c)
The spectroscopy tests (element composition) of the particles showed that $\mathrm{Ca}(27.15 \%)$ is the prevailing element and the other elements are: $\mathrm{Cl}(26.89 \%), \mathrm{O}$ (31.84\%), K (6.85\%), Rb (1.86\%), S (1.16\%), Na (3.65\%), Al (0.60\%) (Figure 3d EDS analysis). Other, partly carbonised particles are also seen, crystallisation reaction products are clearly visible as a porous space filled in part by chaotically distributed needle-shaped particles up to $0.1 \mu \mathrm{m}$ wide (Figure $2 \mathrm{c}$ ).

The following minerals were mainly observed in the FA in the X-ray tests (Figure 3): calcite $\left(\mathrm{CaCO}_{3}\right)$, calcium chloride $\left(\mathrm{CaCl}_{2}\right)$, potassium calcium chloride $\left(\mathrm{KCaCl}_{3}\right)$, potassium chloride $(\mathrm{KCl})$, sodium chloride $(\mathrm{NaCl})$, anhydrite $\left(\mathrm{CaSO}_{4}\right)$. Chloride and sulfate salts mainly prevail in fly ash.

The FA particle size distribution tests revealed that the particle size ranges from $1 \mu \mathrm{m}$ to $100 \mu \mathrm{m}, 10.82 \mu \mathrm{m}$ median size particles make up approx. $50 \%$ of the fly ash (Figure 4).

The X-ray tests of the FA structure showed that all the ceramic bodies with the FA addition contained isomorphous minerals, plagioclase albite-anorthite $(\mathrm{Ca}, \mathrm{Na})$ $(\mathrm{SiAl})_{4} \mathrm{O}_{8}$, calcium sulfate $(\mathrm{CaSO})_{4}$, sodium iron silicates $\left(\mathrm{NaFe}(\mathrm{III})\left(\mathrm{SiO}_{3}\right)_{2}\right.$, hematite $\left(\mathrm{Fe}_{2} \mathrm{O}_{3}\right)$, anorthite

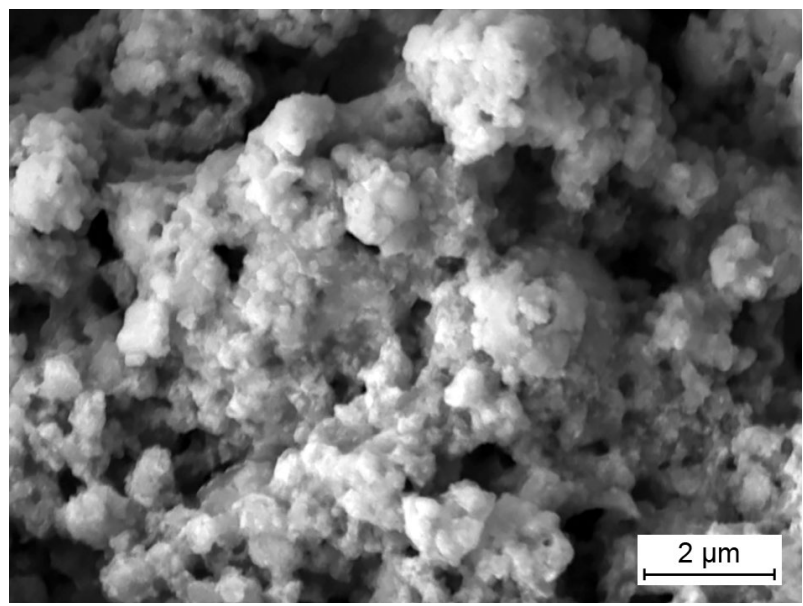

b)

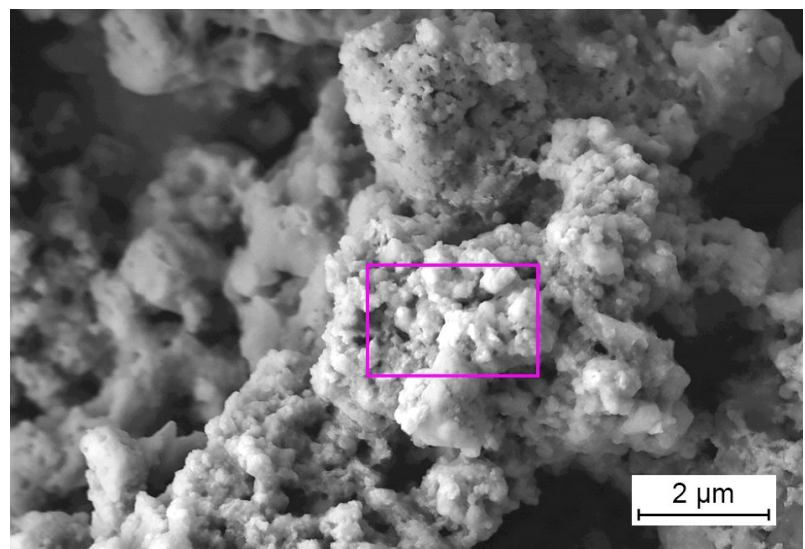

d)

Figure 2. The microstructure of the FA. 
$\left(0.48 \mathrm{Na} \cdot 0.52 \mathrm{Ca} \cdot 1,52 \mathrm{Al} \cdot 2.48 \mathrm{SiO}_{8}\right), \quad$ albite $\quad(0.667 \mathrm{Na}$ $0.33 \mathrm{~K})\left(\mathrm{AlSi}_{3} \mathrm{O}_{8}\right)$, orthoclase $\left(\mathrm{KAlSi}_{3} \mathrm{O}_{8}\right)$, sanidine $\left(\mathrm{K}\left(\mathrm{AlSi}_{3}\right) \mathrm{O}_{8}\right)$, and also quartz $\left(\mathrm{SiO}_{2}\right)$. The peak intensities in the X-ray diffraction (XRD) pattern differ depending on the FA content in the clay brick. Figure 5 illustrates the XRD analysis tests. Quartz $\left(\mathrm{SiO}_{2}\right)$, hematite $\left(\mathrm{Fe}_{2} \mathrm{O}_{3}\right)$,

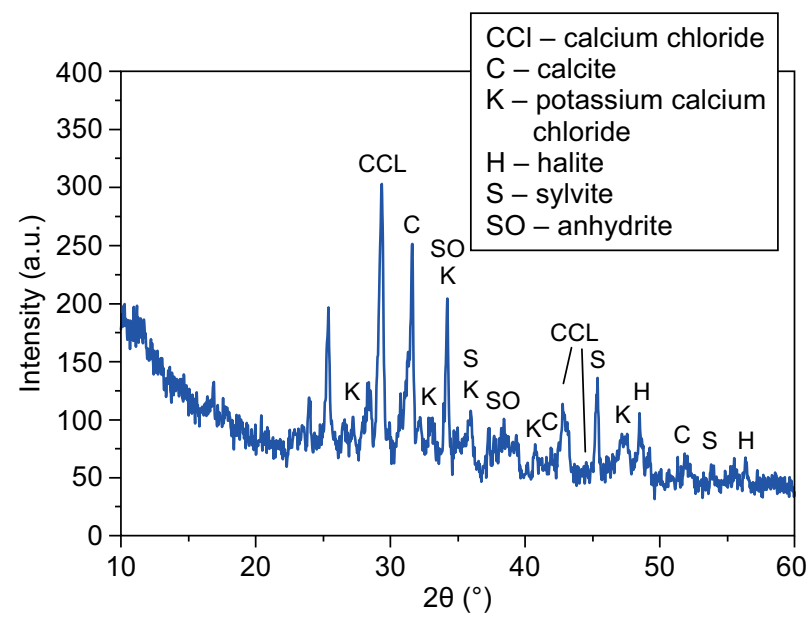

Figure 3. The X-ray diffraction pattern of the FA (nm).

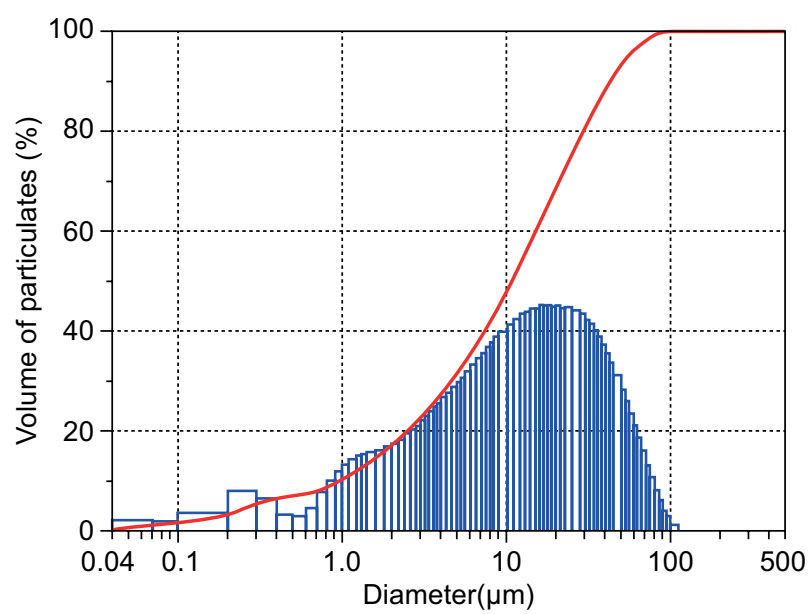

Figure 4. The particle size distribution in the fly ash: a - FA. albite-anorthite $(\mathrm{Ca}, \mathrm{Na})(\mathrm{SiAl})_{4} \mathrm{O}_{8}$, spinel $\left(\mathrm{MgAlO}_{4}\right)$, diopside $\mathrm{MgCaSiO}_{2}$ minerals are identified in the fired reference clay brick, the CS clay brick.

Open pores and defective cracks may develop during the clay brick firing process, then the amount of the liquid phase can be insufficient for the safe immobilisation of all the fly ash particles in the clay matrix and, thus, part of the heavy metals present in the fly ash may leak into the environment. For this reason, the possibility of heavy metal leakage from clay bricks must be evaluated.

The tests of heavy metal leakage from the clay bricks showed that in the clay bricks FA5 and FA7.5 containing $5.0-7.5 \%$ of FA addition, the amount of leached $\mathrm{Cr}$, chlorides and sulfates exceeds the limit values of inert waste set forth in Directive 2003/33/EC.

Although the limit values of the non-hazardous waste set forth in Directive 2003/33/EC have not been reached, we assume that the limit values set for the leaching of inert materials should be observed when hazardous waste, such as MSWI fly ash, is utilised in the manufacturing of building materials. Clay bricks with an FA addition could be used in the construction of residence buildings. Construction products used for

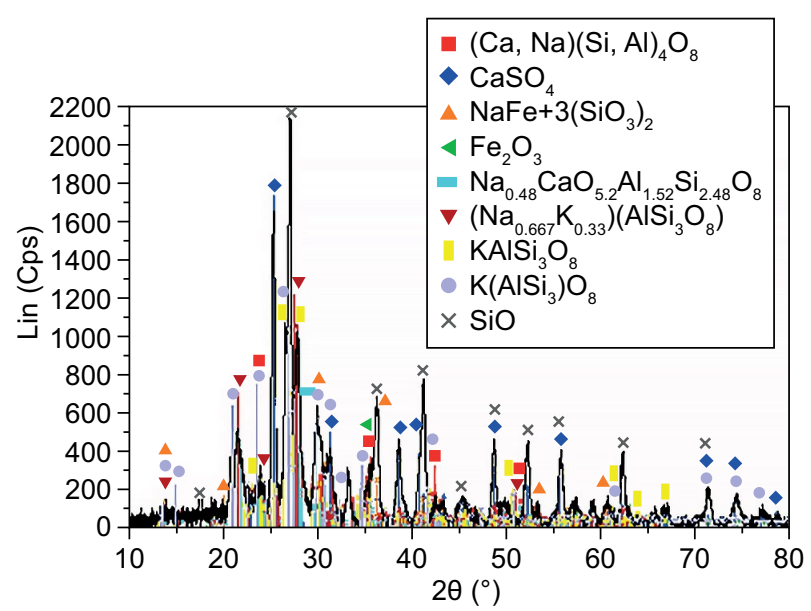

Figure 5. The FA5 X-ray diffraction analysis.

Table 7. The results of testing the $\mathrm{pH}$, Sel (Stream electric conductivity), leaching of heavy metals, chlorides and sulfates from clay bricks.

\begin{tabular}{|c|c|c|c|c|c|c|}
\hline \multirow{2}{*}{$\begin{array}{l}\mathrm{pH}, \text { Sel, heavy metals, } \\
\text { chloride, sulfate values }\end{array}$} & \multicolumn{4}{|c|}{ Clay brick } & \multicolumn{2}{|c|}{ Limit values 2003/33/EC } \\
\hline & $\mathrm{CS}$ & FA 2.5 & FA 5.0 & FA 7.5 & Inert waste & Non-hazardous waste \\
\hline$\overline{\mathrm{pH}}$ & 7.53 & 8.17 & 8.53 & 8.9 & - & - \\
\hline $\operatorname{Sel}\left(\mu \mathrm{S} \cdot \mathrm{cm}^{-1}\right)$ & 355 & 1160 & 1488 & 1887 & - & - \\
\hline $\mathrm{Cu}\left(\mathrm{mg} \cdot \mathrm{kg}^{-1}\right)$ & 0.015 & 0.019 & 0.037 & 0.048 & 2.0 & 50.0 \\
\hline $\mathrm{Cd}\left(\mathrm{mg} \cdot \mathrm{kg}^{-1}\right)$ & 0.0073 & 0.013 & 0.017 & 0.024 & 0.04 & 1.0 \\
\hline $\mathrm{Cr}\left(\mathrm{mg} \cdot \mathrm{kg}^{-1}\right)$ & 0.16 & 0.38 & 0.96 & 1.17 & 0.5 & 10.0 \\
\hline $\mathrm{Pb}\left(\mathrm{mg} \cdot \mathrm{kg}^{-1}\right)$ & 0.028 & 0.055 & 0.087 & 0.093 & 0.5 & 10.0 \\
\hline $\mathrm{Zn}\left(\mathrm{mg} \cdot \mathrm{kg}^{-1}\right)$ & 0.77 & 0.88 & 1.41 & 1.92 & 4.0 & 50.0 \\
\hline $\mathrm{Ni}\left(\mathrm{mg} \cdot \mathrm{kg}^{-1}\right)$ & 0.14 & 0.28 & 0.41 & 0.49 & 0.4 & 10.0 \\
\hline Chloride $\left(\mathrm{mg} \cdot \mathrm{kg}^{-1}\right)$ & 540 & 709 & 1410 & 2120 & 800 & 15000 \\
\hline Sulphate $\left(\mathrm{mg} \cdot \mathrm{kg}^{-1}\right)$ & 2580 & 5600 & 14920 & 15350 & 6000 & 20000 \\
\hline
\end{tabular}


such purpose must not cause any hazards to the environment or human health. Special consideration should be given to the solutions at the end of the life cycle of such bricks. Crushed clay bricks with the FA addition could be recycled in the manufacturing of other building materials. This would implement the principle of a circular economy.

The test results revealed that FA additions reduce the drying and firing shrinkage of the clay bricks (Figure 6). The reference clay brick CS had a drying shrinkage of $9.1 \%$ and a firing shrinkage of $11.2 \%$ when fired at $1000{ }^{\circ} \mathrm{C}$. When $2.5 \%$ FA was added to the moulding compound, the drying shrinkage reduced to $8.3 \%$. When the FA content in the moulding compound was increased from $5.0 \%$ to $7.5 \%$, the drying shrinkage dropped down to $7.0 \%$ and $6.4 \%$, respectively. The drying shrinkage diminishes because the fly ash forms a framework inside the moulded specimen. This framework prevents the clay particles from moving closer to each other during the drying. The non-plastic particles of fly ash stabilise the drying process irrespective of the higher water demand in the forming phase (Table 2).

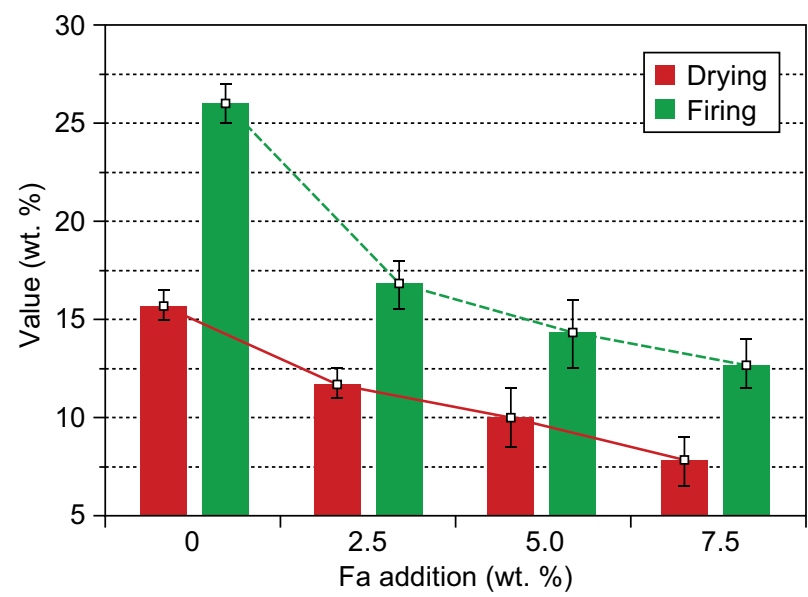

Figure 6. The FA addition reduces the clay brick shrinkage.

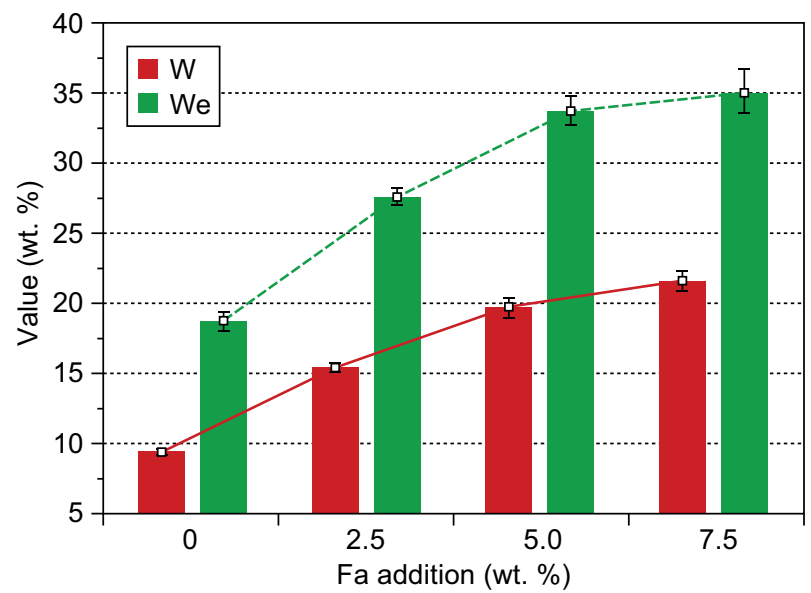

Figure 7. The effect of the FA and FAW addition on the effective porosity and water absorption.
When the moulding compounds with the different FA contents were fired at $1000{ }^{\circ} \mathrm{C}$, no defects, such as swelling or cracking, occurred in the fired clay bricks.

The presence of fly ash particles among the plastic clay particles in the moulding compound influences the development of the additional pore structure in the clay matrix. The liquid phase in the clay during the firing process is not sufficient to fill in that pore structure and the non-plastic fly ash particles between the plastic clay particles and the liquid phase prevent the clay particles from getting closer. This mechanism causes the firing shrinkage and density of the specimens containing the FA addition to reduce and the effective porosity and total porosity of the specimens to increase (Figures 7,8).

The effective porosity of the CS clay brick reaches $18.0 \%$. The addition of $2.5 \%$ FA increases the effective porosity of the clay brick up to $27.5 \%$ and the addition of $7.5 \%$ FA increases the effective porosity of the clay brick up to $34.7 \%$ (Figure 7). The effective porosity describes the structure of the clay brick, characterises the effective potential of the pores and capillaries, i.e., those pores and capillaries, which easily become filled with water; therefore, there is a strong correlation between the effective porosity and the water absorption. The clay brick water absorption tests revealed that $2.5 \%$ of FA addition increases the clay brick water absorption up to $15.3 \%$, whereas with $7.5 \%$ of the FAW addition, the increase is $21.7 \%$.

The FA addition reduces the density of the clay bricks and increases the total porosity (Figure 8 ). The FA addition reduces the density of clay products by $6.25 \%$ down to $1.8 \mathrm{~g} \cdot \mathrm{cm}^{-3}$ and increases the total porosity up to $31.2 \%$ compared to the CS clay brick. The worst results are obtained when $7.5 \%$ of the FA is added to the clay brick. The density of the FA7.5 clay brick is reduced by $16.6 \%$ down to $1.6 \mathrm{~g} \cdot \mathrm{cm}^{-3}$ and the total porosity is increased up to $41 \%$.

The compressive strength of the CS clay brick reaches $35 \mathrm{MPa}$. With $2.5 \%$ of the FA addition, the compressive strength of the clay brick drops to $27 \mathrm{MPa}$.

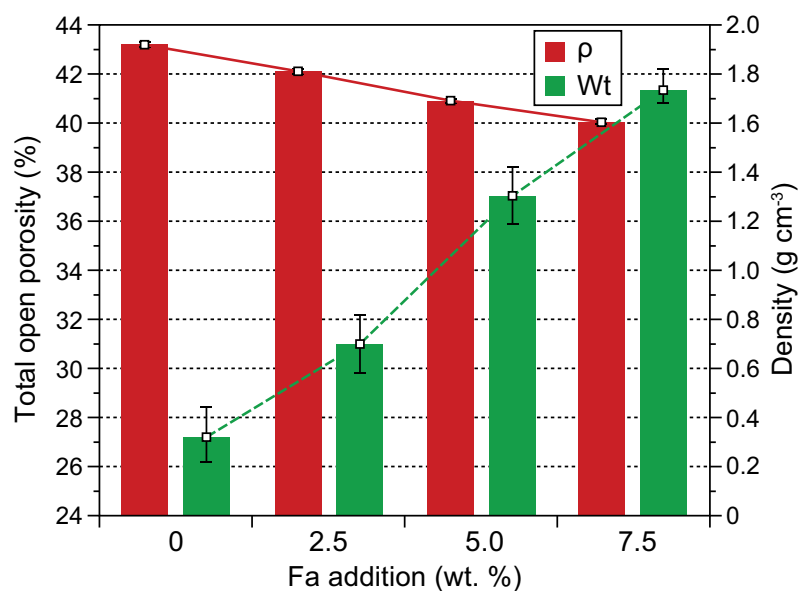

Figure 8 . The effect of the FA addition on the total porosity and density. 
The $7.5 \%$ of the FA addition reduces the compressive strength of the clay brick to $17 \mathrm{MPa}$.

Changes in the FA modified clay brick density, compressive strength, reduced shrinkage, and increased water absorption and porosity is caused by the changes

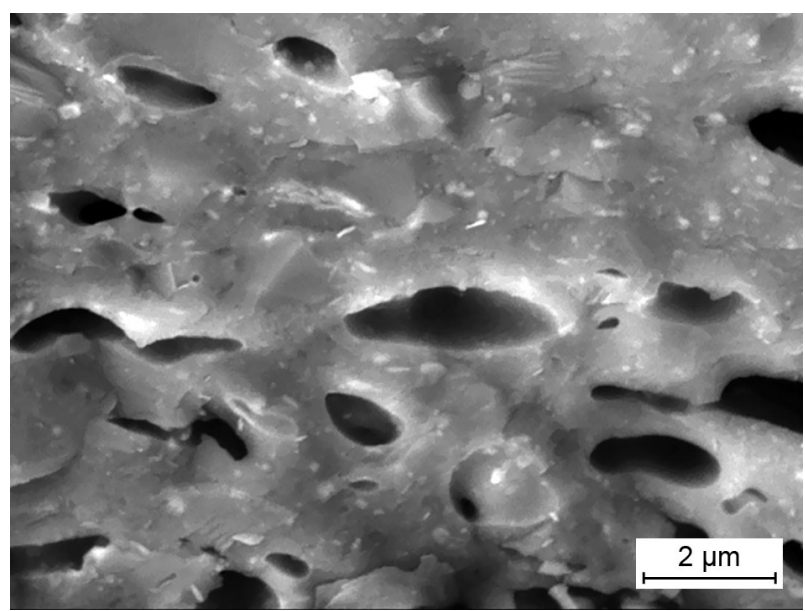

a) $\mathrm{CS}$

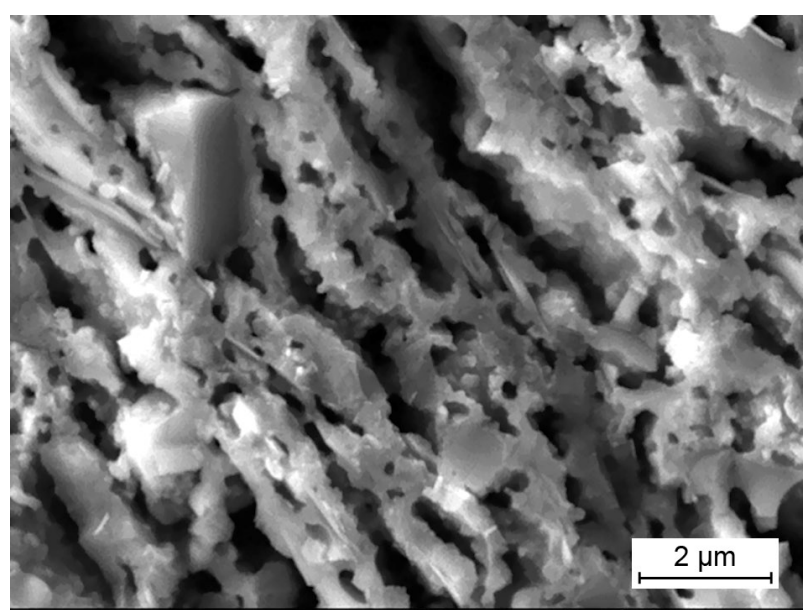

b) FA2.5

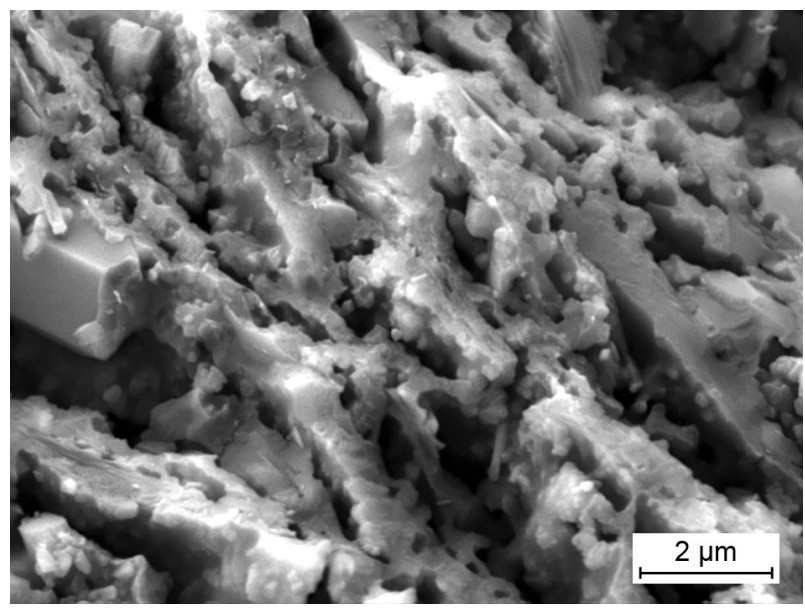

c) FA7.5

Figure 9. The effect of the FA addition on the clay brick microstructure. in the specimen's structure due to the changes on a microstructure level. Waste fly ash additions change the microstructure of the fired clay bricks. This assumption was confirmed by further tests.

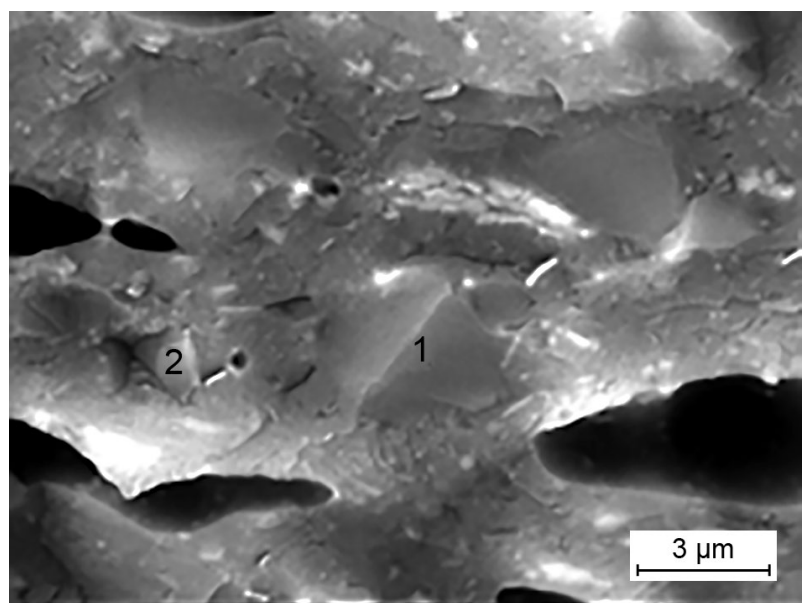

a) $\mathrm{CS}\left(1-\mathrm{SiO}_{2}, 2-\mathrm{Fe}_{2} \mathrm{O}_{3}\right)$

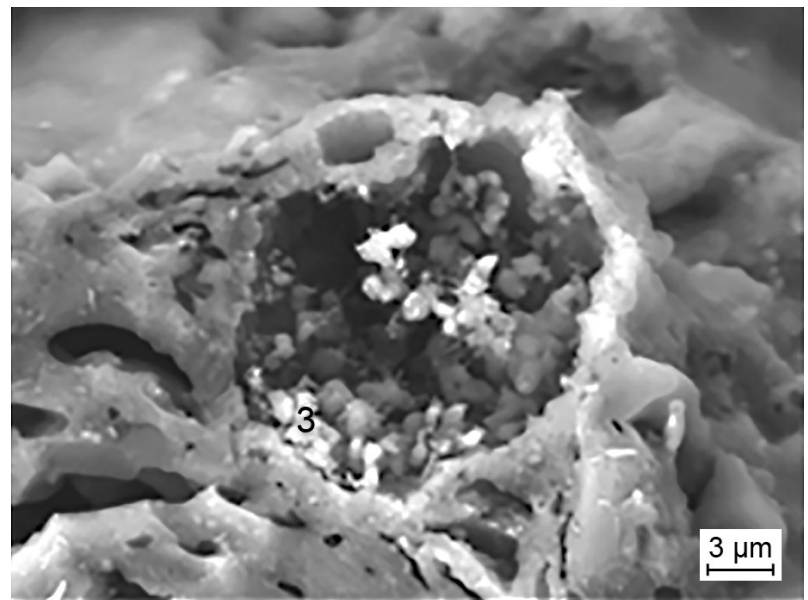

b) $\mathrm{CS}\left(3-\mathrm{MgCaSi}_{2} \mathrm{O}_{6}\right)$

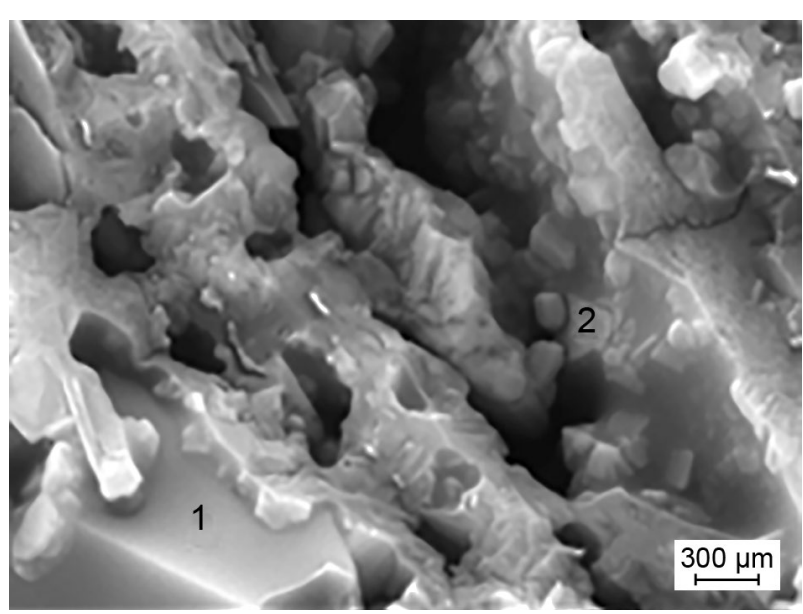

c) $\mathrm{FA} 2.5\left(1-\mathrm{SiO}_{2}, 2-\mathrm{Fe}_{2} \mathrm{O}_{3}\right)$

Figure 10. The effect of the FA addition on the clay brick microstructure, and the identification of the minerals. (Continue on next page) 


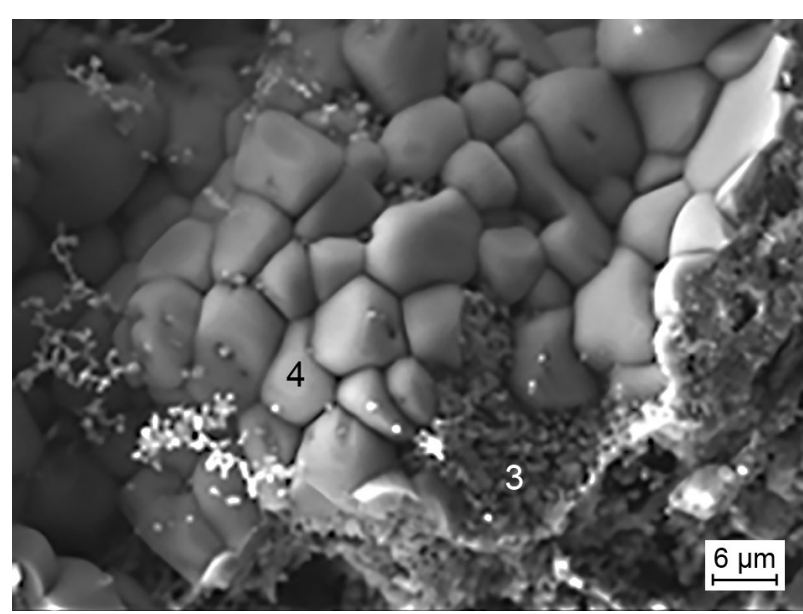

d) FA2.5 (3- $\left.\mathrm{MgCaSi}_{2} \mathrm{O}_{6}, 4-\mathrm{CaSO}_{4}\right)$

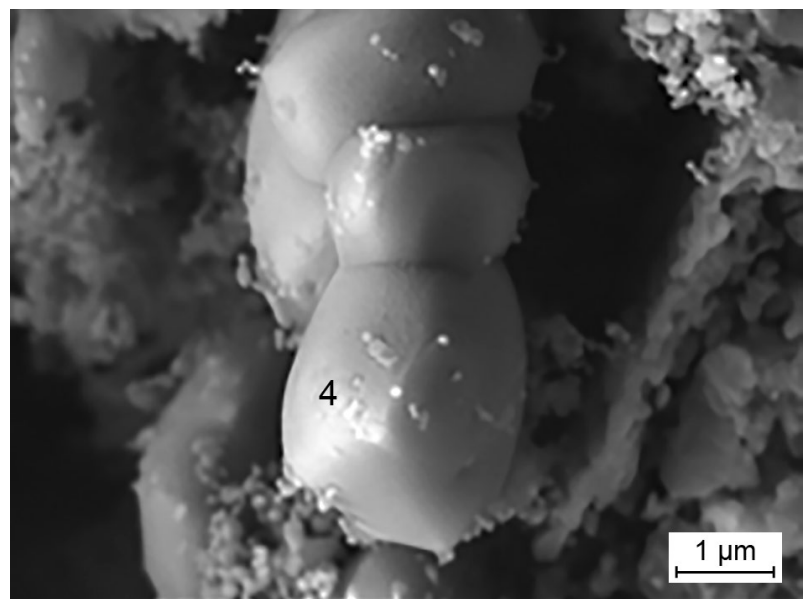

e) FA7.5 $\left(4-\mathrm{CaSO}_{4}\right)$

Figure 10. The effect of the FA addition on the clay brick microstructure, and the identification of the minerals.

The structure of the fired CS clay brick is sufficiently dense and has low porosity. The pores are round and evenly distributed across the entire matrix. No defects or cracks were observed on a microstructure level. It means that the amount of liquid/amorphous phase is sufficient to fill the entire matrix (Figure 9a). The microstructure of the specimens containing the FA addition and fired at $1000{ }^{\circ} \mathrm{C}$ changes (Figure 9b). The pores in the microstructure of the fired clay brick FA2.5 have an elongated form. The pore edges are uneven, the pores are distributed along the entire structure. The tests of specimen FA7.5's microstructure showed a less dense matrix with many elongated shape pores and large round pores. An irregular surface morphology can be observed in specimen FA7.5 (Figure 9c). The obtained microstructure test results correlate with the results of the physical and mechanical characteristics and porosity tests.

The quartz $\left(\mathrm{SiO}_{2}\right)$, hematite $\left(\mathrm{Fe}_{2} \mathrm{O}_{3}\right)$, diopside $\left(\mathrm{MgCaSi}_{2} \mathrm{O}_{6}\right)$ minerals are identified easily in the clay brick microstructure (Figure 10). These minerals form the most often in the fired clay brick. Diopside is formed through the reaction of calcium and magnesium compounds with $\mathrm{SiO}_{2}$ and $\mathrm{Al}_{2} \mathrm{O}_{3}$. The minerals were identified by the EDS tests (Table 8). Figure 10a illustrates that identified particles are closely bound and covered with new reaction products and a constant uniform surface of amorphous/glass phases is formed.

Additionally, calcium sulfate $\left(\mathrm{CaSO}_{4}\right)$ minerals are identified in the clay bricks modified by the FA addition (Figures 10d,e).

Calcium sulfate minerals have a sufficiently large volume and they build up inside the pores most often. There is not any good contact zone between the calcium sulfate minerals and the matrix; therefore, the formation of these minerals causes the increase in the specimen porosity and water absorption and the deterioration in the strength properties (Figuress 7, 8). Besides, the calcium sulfate minerals do not degrade during the firing even at high temperatures. Calcium sulfate can degrade in the presence of oxygen during the firing only at about $1230{ }^{\circ} \mathrm{C}$. The presence of this mineral may also have a negative effect on the durability (freeze - thaw resistance) of the specimens.

In further tests, the resistance of the clay specimens to the freeze-thaw cycles in the one-side and all-sides tests was evaluated. In both methods, the resistance of the specimens to the freezing and thawing cycles was evaluated by visual examination of the types of damage. In the one-side test, all the clay specimens resisted at least 50 freezing and thawing cycles without any noticeable damage. Further tests revealed that the damage, which typically occurs in the one-side freeze-thaw method

Table 8. The EDS spectrum of the fired clay brick.

\begin{tabular}{|c|c|c|c|c|c|c|c|c|c|c|}
\hline \multirow{2}{*}{ Fired clay brick } & \multicolumn{10}{|c|}{ Analysis of all the elements } \\
\hline & $\mathrm{O}$ & $\mathrm{Mg}$ & $\mathrm{Al}$ & $\mathrm{Si}$ & $\mathrm{K}$ & $\mathrm{Fe}$ & $\mathrm{Ca}$ & $\mathrm{S}$ & $\mathrm{Ti}$ & $\mathrm{Zn}$ \\
\hline CS particle 1 & 48.64 & 0.23 & 4.21 & 44.42 & 1.65 & - & 0.75 & - & - & \\
\hline CS particle 2 & 30.61 & 1.98 & 1.20 & 1.57 & - & 62.33 & 0.43 & - & 2.6 & - \\
\hline CS particle 3 & 49.19 & 23.13 & 3.04 & 13.90 & - & 1.23 & 9.1 & - & - & 0.41 \\
\hline FA2.5 particle 1 & 50.06 & 0.11 & 2.18 & 46.12 & 1.12 & - & 0.41 & - & - & - \\
\hline FA2.5 particle 2 & 32.63 & 1.51 & 1.44 & 1.38 & - & 61.21 & 0.70 & - & 1.13 & - \\
\hline FA 2.5 particle 3 & 47.60 & 2.33 & 1.62 & 14.10 & - & 0.27 & 10.08 & - & - & - \\
\hline FA2.5 particle 4 & 58.61 & 0.58 & - & - & - & - & 22.80 & 18.01 & - & - \\
\hline FA7.5 particle 4 & 54.68 & 2.55 & 1.04 & 1.93 & - & 2.79 & 24.86 & 12.13 & - & - \\
\hline
\end{tabular}


Voišnienè V., Kizinievič O., Kizinievič V.

Table 9. The durability (freeze-thaw resistance) of the fired clay brick.

\begin{tabular}{|c|c|c|c|c|c|c|c|c|c|c|c|c|c|c|c|}
\hline \multirow{3}{*}{$\begin{array}{l}\text { Fired } \\
\text { clay } \\
\text { brick }\end{array}$} & \multicolumn{14}{|c|}{ Freezing and thawing method } & \\
\hline & \multicolumn{8}{|c|}{ all-sides tests (after cycles) } & \multicolumn{7}{|c|}{ one-side tests (after cycles) } \\
\hline & 25 & 50 & 75 & 100 & 150 & 200 & 300 & 350 & 50 & 100 & 150 & 250 & 350 & 400 & 550 \\
\hline$\overline{\mathrm{CS} 0}$ & - & - & - & - & - & - & - & - & - & - & - & - & - & - & \\
\hline FA2.5 & - & - & - & $\mathrm{f}$ & & & & & - & - & $\bullet \boldsymbol{\Delta}$ & & & & \\
\hline FA5.0 & - & - & $f$ & & & & & & - & $\bullet$ & $\Delta$ & & & & \\
\hline$\overline{\text { FA7.5 }}$ & - & $\mathrm{f}$ & & & & & & & - & $\bullet \bullet \Delta$ & & & & & \\
\hline
\end{tabular}

Note: - no violations, • surface peeling, $\mathbf{a}$ crack with a width $\leq 1 \mathrm{~mm}$ crack, $\bullet$ crack with a width $>1 \mathrm{~mm}$ crack, $\mathbf{\Delta}$ delamination, $\mathrm{f}-$ fracture

(peeling, spalling, delamination), appeared in the control clay specimens after 550 freeze-thaw cycles, whereas, in the specimens containing the MSWI FA additions, the same damage was observed after 100 (FA5.0 and FA7.5 clay brick) and after 150 (FA2.5 clay brick) freeze-thaw cycles, respectively.

The control ceramic specimens tested by the all-sides method resisted 350 freeze-thaw cycles without any noticeable typical damage (fractures), whereas the specimens with the MSWI FA additions resisted 50-100 freeze-thaw cycles.

According to the requirements reported in the LST EN 771-1:2011+A1:2015 and LST EN 1985:2006 standards and the one-side freeze-thaw test results, the clay brick specimens containing the MSWI FA addition can be used in masonry structures exposed to a medium aggressive environment, i.e., in structures protected from a direct environmental impact. The same finding was confirmed by the all-sides freeze-thaw test results.

The clay brick with the FA addition is a complex, heterogeneous material consisting of quartz, hematite, diopside, calcium sulfate, $\mathrm{Ca}$ and $\mathrm{Mg} / \mathrm{Fe}$-silicates, amorphous/vitreous phases and numerous pores. The change of the constituent minerals and microstructure of the clay brick influences the behaviour under the freezing and thawing conditions.

It should be noted that the FA addition deteriorates the durability (resistance to freezing and thawing cycles) of the clay brick. Presumably the FA addition causes the development of a higher amount of $\mathrm{Ca}$ compounds in the ceramic specimens. As mentioned earlier, the development of these compounds increases the porosity and water absorption of the clay bricks (Figure 7). The increasing porosity and water absorption of the clay bricks has a negative effect on the resistance of the products to the freezing and thawing cycles by both the one-side and all-sides methods. The negative effect of the $\mathrm{Ca}$ compounds on the resistance to the freezing and thawing cycles is also confirmed by other authors [29].

\section{CONCLUSIONS}

The tests revealed that fly ash (FA) influences the mineral composition of the clay brick. The FA addition leads to the formation of $\mathrm{CaSO}_{4}$ minerals, which increase the porosity and water absorption of the specimens and reduce the density and compressive strength.

The leaching tests of the heavy metals, chlorides and sulfates of the clay bricks with the FA addition revealed that the specimens containing $2.5 \%$ of FA do not have leaching values exceeding the limit for non-hazardous waste set in Directive 2003/33/EC.

It is recommended to add $2.5 \%$ of FA to the moulding compounds and fire the bricks at $1000{ }^{\circ} \mathrm{C}$. Such clay bricks have a density of $1.8 \mathrm{~kg} \cdot \mathrm{m}^{-3}$, a shrinkage of $9.4 \%$, a compressive strength of $27 \mathrm{MPa}$, water absorption of $15.3 \%$, and a total open porosity of $31.2 \%$.

According to the durability characteristics determined by the all-side and one-side freeze-thaw methods, the specimens containing the FA addition can be considered as resistant to freezing and thawing under aggressive environment conditions and can be used in masonry structures exposed to such conditions, i.e., structures protected from a direct environmental impact (Class F1 according to EN 771-1:2011+A1:2015).

\section{REFERENCES}

1. Bertolini L., Carsana M., Cassago D., Quadrio Curzio A., Collepardi M. (2004): MSWI Ashes as Mineral Additions in Concrete. Cement and Concrete Research, 34(10), 1899-1906. doi: 10.1016/j.cemconres.2004.02.001

2. Van Herck P., Van der Bruggen B., Vogels G., Vandecasteele C. (2000): Application of computer modelling to predict the leaching behaviour of heavy metals from MSWI fly ash and comparison with a sequential extraction method. Waste Management, 20, 203-210. doi: 10.1016/S0956-053X(99) 00321-9

3. Wunsch P., Greilinger C., Bieniek D., Kettrup A. (1996): Investigation of the binding of heavy metals in thermally treated residues from waste incineration. Chemosphere, 32, 2211-2218. doi: 10.1016/0045-6535(96)00123-3

4. Wang H., Fan X., Wang Y., Li W., Sun Y., Zhan M. (2018): Comparative leaching of six toxic metals from raw and chemically stabilized MSWI fly ash using citric acid. Journal of Environmental Management, 208, 15-23. doi: 10.1016/j. jenvman.2017.11.071

5. Pan J.. R, Huang C., Kuo J.J., Lin C.H. (2008): Recycling MSWI bottom and fly ash as raw materials for Portland cement. Waste Management, 28, 1113-1118. doi: 10.1016/j. wasman.2007.04.009

6. Li X., Chen Q., Zhou Y., Tyrer M., Yu Y. (2014): Stabilization of heavy metals in MSWI fly ash using silica fume. Waste Management, 34 (12), 2494-2504. doi: 10.1016/j. 
wasman.2014.08.027

7. Shi H-S., Kan L-L. (2009): Leaching behavior of heavy metals from municipal solid wastes incineration (MSWI) fly ash used in concrete. Journal of Hazardous Materials, 164 (2-3), 750-754. doi: 10.1016/j.jhazmat.2008.08.077

8. Aubert J.E., Husson B., Sarramone N. (2006): Utilization of municipal solid waste incineration (MSWI) fly ash in blended cement: Part 1: Processing and characterization of MSWI fly ash. Journal of Hazardous Materials, 136 (3), 624-631. doi: 10.1016/j.jhazmat.2005.12.041

9. Tang J., Petranikova M., Ekberg C., Steenari B-M. (2017): Mixer-settler system for the recovery of copper and zinc from MSWI fly ash leachates: An evaluation of a hydrometallurgical process. Journal of Cleaner Production, 148, 595-605. doi: 10.1016/j.jclepro.2017.02.015

10. Remond S., Bentz D.P. (2000): Effects of the incorporation of municipal solid waste incineration fly ash in cement pastes and mortars. Cement Concrete Research, 32, 565-576. doi: 10.1016/S0008-8846(01)00674-3

11. Liu H., Zhao X., Yin H., Chen J., Zhang N. (2018): Intermediate-calcium based cementitious materials prepared by MSWI fly ash and other solid wastes: hydration characteristics and heavy metals solidification behaviour. Journal of Hazardous Materials, 349, 262-271. doi: 10.1016/ j.jhazmat.2017.12.072

12. Arsenovic M., Radojevic Z., Stankovic S. (2012): Removal of toxic metals from industrial sludge by fixing in brick structure. Construction and Building Materials, 37, 7-14. doi: 10.1016/j.conbuildmat.2012.07.002

13. Arsenović M., Radojević Z., Jakšić Z, Pezo L. (2015): Mathematical approach to application of industrial wastes in clay brick production - Part I: Testing and analysis. Ceramic International, 41(3), 4890-4898. doi: 10.1016/j. ceramint.2014.12.051

14. Ye N, Chen Y., Yang Y., Liang S., Hu Y., Xiao B., Huang Q., Shi Y., Hu J., Wu X. (2016): Codisposal of MSWI fly ash and Bayer red mud using a one-part geopolymeric system. Journal of Hazardous Materials, 318, 70-78. doi: 10.1016/j.jhazmat.2016.06.042

15. Shi H-S., Kan L-L. (2009): Leaching behavior of heavy metals from municipal solid wastes incineration (MSWI) fly ash used in concrete. Journal of Hazardous Materials, 164 (2-3), 750-754. doi: 10.1016/j.jhazmat.2008.08.077

16. Liu H., Zhao X., Yin H., Chen J., Zhang N. (2018): Intermediate-calcium based cementitious materials prepared by MSWI fly ash and other solid wastes: hydration characteristics and heavy metals solidification behaviour. Journal of Hazardous Materials, 349, 262-271. doi: 10.1016/j.jhazmat.2017.12.072

17. Jordán M.M., Montero M.A., Rincón-Mora B., Rincón J.M., Sanfeliu T. (2015): Rustic ceramic covering tiles ob- tained by recycling of marble residues and msw fly ash. Fresenius Environmental Bulletin, 24 (2), 533-538.

18. Wan C. (2017). Electrochemical upgrading of different ashes for use in production of bricks. Thesis $\mathrm{PhD}$. Technical University of Denmark, Department of Civil Engineering, ID: 2394007636

19. Belmonte L.J., Ottosen L.M., Kirkelund G.M., Jensen P.E., Vestbo A.P. (2016): Screening of heavy metal containing waste types for use as raw material in Arctic clay-based bricks. Environmental Science and Pollution Research, 1-13. doi:10.1007/s11356-016-8040-Z

20. Haiying Z., Youcai Z., Jingyu Q. (2011): Utilization of municipal solid waste incineration (MSWI) fly ash in ceramic brick: Product characterization and environmental toxicity. Waste Management, 31 (2), 331-341. doi: 10.1016/ j.wasman.2010.10.017

21. Benson C.H., Trast J.M. (1995): Hydraulic conductivity of thirteen compacted clays. Clays Clay Minerals, 43 (6), 669-681. doi: 10.1346/CCMN.1995.0430603

22. Chao-Lung H., Trong-Phuoc H. (2015): Investigation into the use of unground rice husk ash to produce eco-friendly construction bricks. Construction and Building Materials, 93, 335-341. doi: 10.1016/j.conbuildmat.2015.04.061

23. Faria K., Gurgel R., Holanda J. (2012): Recycling of sugarcane bagasse ash waste in the production of clay bricks. Journal Environmental Management, 101, 7-12. doi: 10. 1016/j.jenvman.2012.01.032

24. Andrade F.A., Al-Qurechi H.A., Hotza D. (2011): Measuring the plasticity of clays: A review. Applied Clay Science, 51 (1-2), 1-7. doi: 10.1016/j.clay.2010.10.028

25. Panjaitan S.R.N. (2014): The effect of lime content on the bearing capacity and swelling potential of expansive soil. Journal of Civil Engineering Research, 4, 89-95. doi: 10.5923/c.jce.201402.15

26. Sadunas A. (1997). Durability of aliumosilicate products. VPU, Vilnius.

27. Kersch C., Kraan M., Woerlee G.F., Witkamp G.J. (2002): Municipal waste incinerator fly ash: supercritical fluid extraction of metals. Journal of Chemical Technology and Biotechnology, 77, 256-259. doi: 10.1002/jctb.589

28. An J., Kim J., Golestani B., Tasneem K.M., Muhit B.A., Nam B.H. (2014). Evaluating the Use of Waste-to-Energy Bottom Ash as Road Construction Materials. Final Report, Contract No.: BDK78-977-20, pp.97.

29. Sánchez de Rojasa M.I., Marínb F.P., Fríasa M., Valenzuelab E., Rodríguez O. (2011): Influence of freezing test methods, composition and microstructure on frost durability assessment of clay roofing tiles. Construction and Building Materials, 25 (6), 2888-2897. doi: 10.1016/j.conbuildmat.2010. 12.041 